\begin{tabular}{|l|l|l||}
\hline \multicolumn{2}{|c|}{ PublisherInfo } \\
\hline \hline PublisherName & $:$ & BioMed Central \\
\hline \hline PublisherLocation & $:$ & London \\
\hline \hline PublisherImprintName & $:$ & BioMed Central \\
\hline \hline
\end{tabular}

\title{
Tuning of $\mathrm{T}$ cell activation threshold
}

\begin{tabular}{|l|c|l||}
\hline \multicolumn{2}{|c|}{ ArticleInfo } \\
\hline \hline ArticleID & $:$ & 183 \\
\hline \hline ArticleDOI & $:$ & $10.1186 /$ ar-2000-66810 \\
\hline \hline ArticleCitationID & $:$ & 66810 \\
\hline \hline ArticleSequenceNumber & $:$ & 140 \\
\hline \hline ArticleCategory & $:$ & Paper Report \\
\hline \hline ArticleFirstPage & $:$ & 1 \\
\hline \hline ArticleLastPage & $:$ & 3 \\
\hline \hline & & RegistrationDate : 2000-5-15 \\
\hline ArticleHistory & $:$ & OnlineDate \\
\hline \hline ArticleCopyright & $:$ & Current Science Ltd2000-5-15 \\
\hline \hline ArticleGrants & $:$ & \\
\hline \hline ArticleContext & $:$ & 130753311 \\
\hline \hline
\end{tabular}


Axel Nogai, ${ }^{\text {Aff1 }}$

Aff1 Deutsches Rheumaforschungszentrum, Berlin

\title{
Keywords
}

\author{
Superagonist, T cell tuning, TCR cross-reactivity
}

\section{Context}

$\mathrm{T}$ cells react with a great variety of ligands, and their responses to different ligands are also diverse. This cross-reactivity is considered to play a role in autoimmunity. In the mouse model used in this study, experimental autoimmune encephalomyelitis was induced when the mice were immunized with the peptide PLP139-151 (W144). The variant peptide Q144 induces a nonpathogenic Th2 response. The study investigated whether $\mathrm{T}$ cell proliferation due to either of these ligands has an effect on the outcome of $\mathrm{T}$ cell reactions to different peptides in vivo. To investigate the influence of repeated $\mathrm{T}$ cell stimulation with different ligands on $\mathrm{T}$ cell reactivity.

\section{Significant findings}

A T cell line was maintained for one year by stimulating the cells with the suboptimal ligand W144. Only small amounts of Th1 cytokines were produced by some clones after stimulation with W144; however, stimulation with Q144 led to a stronger proliferative response and to detectable amounts of Th1 cytokines in many clones. The lines were stimulated either with the stronger activator Q144 or with the suboptimal ligand W144 four times. While the dose-response curves of some clones reacting to Q144 and W144 did not change when the clones were stimulated with Q144, other clones lost most of their sensitivity to all peptides. When cytokine production was investigated it appeared that stimulated $\mathrm{T}$ cells produced the same levels of IL-4 and IL-10 when the clones were stimulated with either ligand, W144 or Q144. However, clones cultured with Q144 did not produce any Th1 cytokines after stimulation with any peptide, in contrast to clones stimulated with the suboptimal ligand W144. These clones produced Th1 cytokines when stimulated with the hyperoptimal ligand Q144. While there was no change of the TCR, CD4 or CD28 during the first three rounds of restimulation, after 10 rounds of restimulation the number of CD4-negative cells increased significantly.

\section{Comments}


It has recently become obvious that $\mathrm{T}$ cell cross-reactivity occurs frequently. Furthermore, it has been shown that $\mathrm{T}$ cell activation by different ligands can result in different outcomes, for example, cytokine production and proliferation. It was presumed, however, that the effects of a ligand on the T cell would not change over time, once the $\mathrm{T}$ cells had reached a preactivated state. In this article, Nicholson et al demonstrate that repeated stimulation of $\mathrm{T}$ cells with suboptimal and hyperoptimal ligands after a longterm culture can change the threshold for T cell proliferation and cytokine production. Although these results are interesting, it should be investigated whether these in vitro results are also in vivo phenomena and not just artefacts.

\section{Methods}

Female SJL mice were immunized with the peptide Q144. After 10 days, lymph node cells were cultured and restimulated twice in the presence of the cross-reactive peptide W144, which is a suboptimal ligand compared with Q144. Limiting dilution assay was performed. The cells were of a diverse population, as indicated by different V? usage. Cells were cultured for at least a year by restimulation with W144. Proliferation was measured by incorporation of radioactively labelled thymidine. Cytokine production was determined by ELISA. Expression of surface molecules was perfomed by FACS.

\section{References}

1. Nicholson LB, Anderson AC, Kuchroo VK: Tuning T cell activation threshold and effector function with cross-reactive peptide ligands. Int Immunol. 2000, 12: 205-213.

This PDF file was created after publication. 